\title{
Partner, Industry, Characteristics and Venture Capital Investment Performance
}

\author{
Yuxin Ning ${ }^{1^{*}}$ and Huanying Wang ${ }^{2}$ \\ 1 Economics and Management school, Xi'an Shiyou University, P. R. China,710065 \\ 2 Economics and Management school, Xi'an Shiyou University, P. R. China,710065 \\ 3 School of Economics and Management, Faculty of Accounting and Finance, \\ Xi'an Shiyou University \\ nyx91@sina.com, 2859293613@qq.com
}

Keywords: Partners; Industry characteristics; Listed companies; Venture capital performance

\begin{abstract}
This paper from the perspective of business partners and industry characteristics, researches the 224 companies listed on the board with the background of venture capital of Shenzhen 2009-2016,constructs the performance indicators of venture investment from two aspects, one is output level, another is benefit level. Using empirical test studies the influence on venture capital investment performance in the role of venture partners and industry characteristics. Research shows that: In the economic background of listed companies, venture capital partners effect showed negative influence; Associate degree of partners and the characteristics of the industry will have a significant negative correlation on venture capital investment performance, but in the field of new and high technology industry, the selection of certain characteristics of the industry positively have active influence on the benefit level performance of venture capital investment; The holding time of venture capital project has a significantly positive effects on the output level of venture capital investment performance.
\end{abstract}

\section{Introduction}

With the gradual improvement of China's capital market, venture capital as a support of entrepreneurs entrepreneurial tools can not only ease the financing problems of entrepreneurs, achieve financial innovation pattern of entrepreneurs, but also adjust the industrial structure and change the mode of economic development from the aspects of the management and integration of resources. Venture capital originated in the US in 1940s, and venture capital enterprises in China entered the stage of vigorous development along with the launch of partnership business law and gem.

In the operation of venture capital, from the pre investment assessment decision to the post investment supervision, each link is closely linked and ultimately affects the investment performance. The monitoring function and close participation ability of venture capital institutions are important factors to achieve high returns and good investment performance of listed companies. Bottazzi et al. (2008) study the relationship between the human resources background of venture capital institutions and supervision management behavior, found that if the venture capital institutions has more experience with business partners, then the institutions will be more positive to the invested company's supervision and management. Baum and Silverman (2004) think that when venture capitalists are selecting start-ups, they will be more willing to choose companies that have the characteristics of technological advantages. This makes more and more VC firms tend to focus on a specific industry or field to invest professionally .

In recent years, the view about venture capital will help improve the investment performance of listed companies has been widely recognized by the community, Mu Zhirong (2012) and other scholars also obtained the conclusion that venture capital has a positive impact to business performance of venture enterprises through research data, therefore, in venture capital, capital partners and resources of entrepreneurs (industry characteristics) are the important factors of 
entrepreneurial success. So, how do venture capital institutions and start-ups make a two-way choice? What is the impact of entrepreneurs' partners on investment performance? Does the industry characteristic of the enterprise has an impact on the performance of the enterprise's investment? This paper carries out empirical research to illustrate the above problems through relevant data, and provides theoretical and practical support and guidance for the scholars who study this topic in the future.

\section{Theoretical Analysis and Research Hypothesis}

The formation of entrepreneurial enterprises is closely related to capital support and cooperation between venture capitalists and other partners. The reason is that most of venture capital funds come from insurance companies, bank trust funds, investment funds and other individuals and families with surplus funds. The theory of agency thinks the process of venture capital existing in the three, venture capital institutions, venture investors and venture enterprises (entrepreneurs), between the three subjects, has a dual agency relationship, the first layer of agency relationship between risk investor and venture investment institutions, the risk of investors as the principal, venture capital institutions as the agent, for risk investors entrust funds to venture capital institutions to take part in mechanism of management and operation; the second agent relation lies in venture capital and venture enterprise (entrepreneurs), among them, venture capital institutions as the principal, business enterprises (entrepreneurs) as the agent, venture capital institutions will have their own capital, experience and technology resources entrusted to the enterprise (entrepreneurs), to achieve the implementation of high returns. This paper mainly studies the second layer principal-agent relationship. This layer of principal-agent relationship based on the existence of information asymmetry caused the existence of serious agency problems: Entrepreneurs to pursue private benefits and damage the interests of venture capital institutions; The entrepreneurs have the incentive effect of excessive investment, causing the formation of non effective continuity problems. Therefore, the two-way choice between venture capital institutions and entrepreneurial entrepreneurs is particularly important.

Hisrich thinks that the process of venture capital institutions select start-ups should include: looking for projects, self standard screening and standard screening of venture capital institutions, the first stage assessment (assessment of the value of the project), the second phase of the assessment (assess investment barriers of projects), signing investment, in the six stages, the most important is the enterprise's "potential factors", which including the entrepreneur's business background, reputation and experience, the characteristics of the industry, enterprise technology, asset strength and social relationship. Silverman's (2004) research found that venture capital institutions not only choose those who have joint network and human capital, but also prefer the enterprises with strong risk but strong technological advantage when they choose entrepreneurial enterprises and give full play to their managerial advantages.

The learning hypothesis points out that as venture capital institutions deepen their understanding of enterprises, if they continue to invest in a specific type of enterprises, they will get the maximum benefit from the learning effect curve through knowledge and experience accumulation, and increase the investment success rate. On the contrary, according to the theory of resource capacity, that is, the heterogeneity of resources and capabilities between organizations, the more venture capital institutions participate in entrepreneurial enterprises, the more concentrated the diversity resources are, the more effective information and suggestions can be provided for start-ups. According to Sapienza (1992) of the empirical research, found that the venture capital mechanism on enterprise knowledge input is proportional to the number of institutions involved in investment, when the enterprises with new ideas, new projects to attract venture capital institutions to invest in the project, the cluster effect of venture capital institutions internally generated will drive other venture capital institutions to make the same decision and invest in the same company, which make the number of venture capital institutions and enterprises increased and corporate reputation enhanced, that is, the number of venture investment institutions to participate in the role of signal transduction, attract more organizations to participate in the same business investment, along with 
the deepening of cooperation between venture capital institutions, this will further expand the overall strength of the investment side, and have the positive impact of the survival and development of enterprises. According to this, the hypothesis 1 is proposed.

Hypothesis 1: the more the number of partners and the closer cooperation, the more intensive the venture capital network is, the more conducive to improving the investment performance of venture capital.

The venture capital institutions, cooperate with entrepreneurial enterprises, select the project concerned with certain characteristics of the industry. Those with high growth, new products and technology, meeting the market demand of the industry, opening up new business services such as high-tech projects, easy to form capital and management experience of venture capital institutions demand, these projects will be selected by venture capital institutions, to create greater value for their investment and the holding project, and to improve the performance of investment. Traditional financial theory holds that if the industry of venture enterprises has the characteristics of high risk and high return, reducing costs can increase earnings accordingly, thereby improving the investment performance of venture capital institutions. Manigart (2006) believes that the enterprise has the high risk due to the high level of information asymmetry in the early stage, so the higher income will be obtained accordingly. According to the theory based resources, the key to decision whether the venture capital is successful or not depends on the organization can grasp the industry's proprietary knowledge, skills and relationship resources. Therefore, venture capital institutions will take the initiative to invest in a particular industry characteristics of the enterprise, although enterprises have high costs in the early stage, mainly in the early development of R\&D personnel, technology, innovation investment in R\&D funds, with the venture capital institutions gradually understand the entrepreneurial enterprises, $R \& D$ personnel gradually mastered the technology and with the development of start-ups and maturity of technology, gradually reduce the cost will promote the corresponding income increase, and this income is reflected in the book return multiplier (BR) and the internal rate of return (IRR) and other indicators.

From the professional point of view of investment in the industry, Gupta, Sapienza (1992) and Franke (2006) found different industries will have different effects on the investment performance; Dimov and Clercq (2006) found that the professional degree of venture capital investment industry is set, the higher the success rate of investment. At the same time, we found that decision making of venture capital institutions in the choice of the project is bound to have an advance understanding about representative index of the industry characteristics, such as enterprises' R\&D expenditure and the proportion of $R \& D$ personnel through literature, some venture capitalists are preference for invest more research personnel, high technical $\mathrm{R} \& \mathrm{D}$ costs, some tend to invest more core technological products, even much literature study the relationship of high risk industry between venture investment, innovation enterprises and high-tech enterprises, for this kind of high risk industry, when there is a high risk, there is a high yield. Therefore, we have reasons to believe that venture capital institutions will also choose industries with specific characteristics to invest when selecting venture businesses, and investing in specialized industries will help to get better investment returns. According to this, the hypothesis 2 is proposed.

Hypothesis 2: in the field of high and new technology, its obvious industry characteristics have a positive impact on the investment performance of venture capital.

Relying on the life cycle theory, the venture capital cycle includes three stages: the raising, investment and withdrawal of venture capital. Venture capital usually invests in entrepreneurial firms who have the potential investment projects, and venture capitalists are mostly from the business and financial elite, they have good reputation of the industry qualifications and experience, therefore they accomplish the task with ease especially to evaluate investment projects and form the risk of enterprises. Based on the signal theory, venture capitalists usually select relevant indicators as signals to reflect the status of the project, such as the holding time of expected project and market share. Kaplan and Stromberg (2000) studied 58 investments in 42 enterprises invested by 10 venture capital institutions, and found that when selecting investment projects, venture capitalists will carefully consider the factors such as expected holding time, product market share and 
competition situation. Xu Chengming (2009) from the perspective of holding time in rventure capital project, he divides the 433 listed companies with support of venture capital institutions into two categories of young and mature in the year of 1978-1987, found the younger companies with the support of venture capital will be IPO on an average of 56 months, and the mature institutions will IPO on an average of 80 months, and the latter who hold a long time inventure capital project will get good return on investment performance. Gompers, Lerner (1998) analysis 419 limited partnership agreements in 1978-1992, found that risk investors are unwilling to have frequent change and early liquidation to their holding projects because of incentive effect, for mature venture capital institutions tend to gain more variable compensation, while the young venture capital institutions are more rely on fixed compensation, this has a certain extent to prove the length of time to hold the project can produce the promoting effect on venture capital institutions. Based on the above theoretical analysis, the hypothesis 3 is proposed.

Hypothesis 3: the longer the venture capital investment project is holding the venture investment project, the more it can improve the performance of venture capital.

According to the resources based theory, the cooperation of many institutions enriches the whole knowledge and resources, and can bring greater benefits to the development of the funded enterprises. Concretely embodied as follows: Partners selecting: venture capital institutions will choose partners with strong heterogeneity, will have their own unique skills, resources and other organization knowledge, experience and social network resources integration, to provide more comprehensive supervision and guidance for the enterprises, and to increase the possibility of success of the venture investment; Industry characteristics: Lerner (1994) pointed out that in the early stage of enterprise development, the venture capital institutions with strong strength tend to choose the institutions of the same strength; Du (2009) from the perspective of the type of research institutions reached a similar conclusion, venture capital is more inclined to choose the venture capital institutions with smaller differences to collaborate, so we believe that different entrepreneurial characteristics in different industries will make the elected types of investment differ; Investment experience: due to the heterogeneity between the venture capital institutions, venture capital institutions will produce the cluster effect in the process of investment, small venture capital institutions are more likely to respond to a large venture capital institutions or institutions having rich experience in investment, and large venture capital institutions have agglomeration effect in credit, scale and influence, resulting in a large number of venture capital institutions to invest in one or several enterprises, not only make the enterprises partner number increase, venture capital institutions correlation enhance, but also greatly improve the accuracy of investment projects through selected specific characteristics of industries, enrich entrepreneurial enterprises overall strength.

The development of entrepreneurial enterprises cannot do without its own profession setting, such as R\&D personnel proportion, R\&D funding ratio, core technology products, the potential abilities and the holding time of venture capital project, by contrast, the establishment of venture capital institutions has a closely relationship with venture enterprises, a large number of entrepreneurial enterprises, long time cooperation as well as the closely relationship are conducive to mutual development between the two sides, and the best interests of both sides is reflected in the book return multiplier and the internal rate of return on investment, to achieve a high rate of return. According to this, the hypothesis 4 is proposed.

Hypothesis 4: the joint selection of partner relevance and industry characteristics will have a positive impact on the performance of venture capital investment.

\section{Empirical Research Design}

Sample Selection and Data Sources. Sample Selection. The initial sample of this study is 498 listed companies in the Shenzhen Stock Exchange from 2009 to 2017, we regard these sample statistics as cross section data, based the information disclosure status of listed company, and combined with the related data of Wind database and the prospectus, we exclude 265 listed companies who have no venture capital background, missing data and model outliers, and finally 
obtained 233 primary research samples. Due to the initial estimates for the company's partners and industry characteristics of the samples, to better reflect the influence of them on the venture capital performance of listed companies, therefore, according to the relevant variables such as partners, industry characteristics, we use the same method eliminates abnormal data, which have an impact in model results and test values, finally, we determine the partner sample is 233 , the characteristics of the industry sample is 224 , the high-tech industry with obvious characteristics for a sample of 77 , determine the cross variable partners and industry characteristics sample is 224 . In order to ensure the consistency of the selected samples and the comparability of the measurement results, we finally determined the independent variable risk capital network and cross variables with the same sample of 224, and identified 77 samples of high-tech industries with obvious industry characteristics.

Sources of Data. The initial data and the final samples are originated by the Wind database and the prospectus of the listed companies. Due to the selection of research models and the setting of data variables, the selected sample data and other data were collected manually, and unified. Excel and Eviews8.0 softwares are used for modeling and analysis.

\section{Variable Selection.}

Interpreted Variable. The interpreted variable is the venture capital investment performance, direct measurement and indirect measurement are two methods, the direct measure refers to the use of income data directly to measure venture capital investment performance, while the indirect measure refers to the non income data indirectly to measure venture capital investment performance.

Explaining Variables. Because we study this paper from the perspective of investment performance of listed company's partners and industry characteristics, although previous studies in the characteristics of the industry and partners is very little, in the initial stage of the data collection and on the basis of the previous study, the final selection of explaining variables are redefined as: (1) partners: the number of partners and partners association degree; (2) the characteristics of the industry: research staff ratio and the proportion of $R \& D$ fund, because the factors of venture capital institutions' investment project are complex and subjective, research staff ratio and $R \& D$ ratio in enterprises not only reflect the feasibility and innovation of investment project, also can reflect the scale of technology investment and overall strength, there is a certain basis to judge whether the venture capital institutions tend to invest a significant feature of the industry; (3) the project: the holding time of the venture capital project.

Controlled Variables. On the basis of existing data, and taking into account the availability of data, this paper introduces three types of controlled variables, the first class reflects the characteristics of entrepreneurial enterprises, using the specific setting time of listed companies and whether the companies belongs to the high risk industry to represent; the second class reflects the characteristics of venture capital institutions, specifically expressed by leading venture capital institutions reputation; the third category is expressed by total assets and asset liability ratio of listed firms, the total asset are treated logarithmically. Specific explanation are shown in table 1. 
Table 1 The Explanation of Research Variables

\begin{tabular}{|c|c|c|c|}
\hline Variable name & $\begin{array}{l}\text { Variable } \\
\text { symbol }\end{array}$ & Variable description & $\begin{array}{c}\text { data } \\
\text { sources }\end{array}$ \\
\hline \multirow[t]{2}{*}{ Interpreted Variables } & $\mathrm{BR}$ & $\begin{array}{c}\text { (cumulative withdrawal } \\
\text { amount-total amount of } \\
\text { investment)/total amount of } \\
\text { investment }\end{array}$ & \multirow[t]{4}{*}{$\begin{array}{c}\text { Wind } \\
\text { database }\end{array}$} \\
\hline & IRR & $\begin{array}{c}(1+\mathrm{BR})^{\wedge}(1 / \mathrm{T})-1, \mathrm{~T} \text { is the holding } \\
\text { time of the venture investment } \\
\text { project(unit:day) }\end{array}$ & \\
\hline \multirow{5}{*}{ Explaining Variables } & VC_Number & $\begin{array}{l}\text { the number of venture capital } \\
\text { institutions }\end{array}$ & \\
\hline & $\begin{array}{l}\text { VC_Relations } \\
\text { hip }\end{array}$ & $\begin{array}{l}\text { amount of investment/total fund } \\
\text { raising }\end{array}$ & \\
\hline & $\begin{array}{c}\text { Research Staff } \\
\text { Ratio(RSR) }\end{array}$ & $\begin{array}{l}\text { the staff of research and } \\
\text { development/total number of } \\
\text { employees }\end{array}$ & \multirow{2}{*}{$\begin{array}{l}\text { prospectu } \\
\text { s of listed } \\
\text { firms }\end{array}$} \\
\hline & R\&D Ratio & $\begin{array}{l}\text { R \& D investment/business } \\
\text { income }\end{array}$ & \\
\hline & VC_Period & $\begin{array}{l}\text { the holding time of the venture } \\
\text { investment project(unit:day) }\end{array}$ & \multirow{5}{*}{$\begin{array}{c}\text { Wind } \\
\text { database }\end{array}$} \\
\hline \multirow[t]{5}{*}{ Controlled Variables } & Hrindustry & $\begin{array}{l}\text { whether it belongs to the new } \\
\text { energy, new media, finance, } \\
\text { biotechnology, medical or } \\
\text { information technology industry, } \\
\text { belong is } 1 \text {, or is } 0\end{array}$ & \\
\hline & AGE & $\begin{array}{l}\text { the difference between the date } \\
\text { of listing and the date of } \\
\text { establishment (unit: day) }\end{array}$ & \\
\hline & $\begin{array}{c}\text { VC_Reputatio } \\
n\end{array}$ & $\begin{array}{c}\text { investment in the leading venture } \\
\text { capital institution/total } \\
\text { investment in venture capital }\end{array}$ & \\
\hline & Size & total assets & \\
\hline & Debit & asset liability ratio & $\begin{array}{l}\text { prospectu } \\
\text { s of listed } \\
\text { firms }\end{array}$ \\
\hline
\end{tabular}

\section{Empirical Analysis and Test}

Model Design. This paper chooses the multiple linear regression model, that isthe model: $Y_{\mathrm{t}}=\beta_{0}+\beta_{1} x_{1}+\beta_{2} x_{2}+\ldots \ldots \beta_{\mathrm{j}} x_{\mathrm{t}}+\varepsilon(\mathrm{j}=0,1, \ldots, n ; t=1,2, \ldots, n), Y_{t}$ is the interpreted variable, ${ }_{t}$ is the explaining variable, ${ }^{\beta}{ }_{j}$ is a regression coefficient and ${ }^{\varepsilon}$ is a random error term.

Based on the above theoretical analysis and hypothesis, it is assumed that hypothesis 1 is the following:

$$
\begin{aligned}
& V C_{-} \text {Performance }=\beta_{0}+\beta_{1} V C+\text { Number }+\beta_{2} \text { Hrindustry }+\beta_{3} A G E+ \\
& \beta_{4} V C_{-} \text {Re putation }+\beta_{5} \text { Size }+\beta_{6} \text { Debit }+\varepsilon
\end{aligned}
$$




$$
\begin{aligned}
& V C_{-} \text {Performance }=\beta_{0}+\beta_{1} V C \text { Re lationship }+\beta_{2} \text { Hrindustry }+\beta_{3} A G E+ \\
& \beta_{4} V C_{-} \text {Re putation }+\beta_{5} \text { Size }+\beta_{6} \text { Debit }+\varepsilon
\end{aligned}
$$

$V C_{-}$Performance represents the performance of venture capital. Themodel of hypothesis 2, hypothesis 3 and hypothesis 4 are all based on the model 1 .

Empirical Analysis. Descriptive Statistics and Analysis. Table 2 gives descriptive statistics between the sample variables used in this article. The results showed that the interpreted variables BR, explaining variables VC_relationship, research staff ratio (RSR) and R\&D ratio have a larger overall fluctuation, indicating that their development stages are uneven. At the same time, the number of VC_number is unbalanced, the number of research staff ratio is not equal, and the difference between $\mathrm{R} \& \mathrm{D}$ ratio is too large. It shows that enterprises are still in the early stage of VC development when they are listed, which provides a basis for exploring venture capital performance of listed companies.

Table 2 Descriptive Statistics of Variables

\begin{tabular}{|l|l|l|l|l|l|l|}
\hline VARIABLES & MAX & MIN & $\begin{array}{l}\text { AVERAG } \\
\text { E }\end{array}$ & $\begin{array}{l}\text { MEDIA } \\
\text { N }\end{array}$ & $\begin{array}{l}\text { STEDV. } \\
\text { S }\end{array}$ & Samples \\
\hline BR & 28.690 & 0.1 & 5.472 & 3.927 & 5.078 & 224 \\
\hline IRR & 0.039 & $\begin{array}{l}7.050 \mathrm{E}-0 \\
5\end{array}$ & 0.002 & 0.002 & 0.003 & 224 \\
\hline VC_Number & 14 & 1 & 3.589 & 3 & 2.508 & 224 \\
\hline $\begin{array}{l}\text { VC_Relations } \\
\text { hip }\end{array}$ & $\begin{array}{l}104.756 \\
\%\end{array}$ & $0.421 \%$ & $11.758 \%$ & $8.231 \%$ & $11.758 \%$ & 224 \\
\hline RSR & $93.590 \%$ & $3.333 \%$ & $27.468 \%$ & $21.735 \%$ & $18.903 \%$ & 224 \\
\hline R\&D Ratio & $80 \%$ & $1.090 \%$ & $6.211 \%$ & $4.665 \%$ & $6.601 \%$ & 224 \\
\hline VC_Period & 4294 & 29 & 995 & 864 & 569 & 224 \\
\hline Hrindustry & 1 & 0 & 0.344 & 0 & 0.476 & 224 \\
\hline AGE & 9226 & 394 & 3917 & 3601 & 1533 & 224 \\
\hline $\begin{array}{l}\text { VC_Reputatio } \\
\text { n }\end{array}$ & $100 \%$ & $22.774 \%$ & $69.898 \%$ & $66.667 \%$ & $24.733 \%$ & 224 \\
\hline Size & $2.88 \mathrm{E}+09$ & 66241.87 & $4.61 \mathrm{E}+08$ & $\begin{array}{l}3.65 \mathrm{E}+0 \\
8\end{array}$ & $3.5 \mathrm{E}+08$ & 224 \\
\hline Debit & $75.690 \%$ & $3.800 \%$ & $37.841 \%$ & $37.715 \%$ & $15.835 \%$ & 224 \\
\hline
\end{tabular}

In order to verify whether there is a common linear problem between the interpreted variables, the Pearson correlation analysis is carried out and shown in table 3 . The results show that the correlation coefficient between the interpreted variables is less than 0.5 , and there is no multiple collinear problem. At the same time, VC_number and VC_relationship have negative significant to BR at the 0.01 significant level, similarity, VC_number and VC_relationship have negative influence to TRR at the 0.05 significant level, these decisions provide model 1 with preliminary judgment, also provide the negative significant basis for cross variables. It is worth noting that the interpreted variables such as VC_number, VC_relationship and VC_Period are correlated with each other. research staff ratio is correlated with $R \& D$ ratio, but they are designed separately in different models, so they are independent and statistically significant. 
Table 3 Explanatory Variable Correlation (Person Correlation Coefficient Test)

\begin{tabular}{|l|l|l|l|l|l|l|l|}
\hline & BR & IRR & $\begin{array}{l}\text { VC_num } \\
\text { ber }\end{array}$ & $\begin{array}{l}\text { VC_Relatio } \\
\text { nship }\end{array}$ & RSR & $\begin{array}{l}\text { R\&D } \\
\text { ratio }\end{array}$ & $\begin{array}{l}\text { VC_Peri } \\
\text { od }\end{array}$ \\
\hline BR & 1 & $\begin{array}{l}0.195^{* *} \\
*\end{array}$ & $-0.252^{* * *}$ & $-0.395^{* * *}$ & -0.013 & -0.037 & -0.097 \\
\hline IRR & $\begin{array}{l}0.195^{* *} \\
*\end{array}$ & 1 & $-0.155^{* *}$ & $-0.212^{* * *}$ & 0.004 & -0.055 & $0.480^{* * *}$ \\
\hline VC_Number & $\begin{array}{l}-0.252^{*} \\
* *\end{array}$ & $\begin{array}{l}*-155^{*} \\
*\end{array}$ & 1 & $0.479 * * *$ & 0.038 & 0.004 & $-0.133^{* *}$ \\
\hline $\begin{array}{l}\text { VC_Relation } \\
\text { ship }\end{array}$ & $\begin{array}{l}-0.395^{*} \\
* *\end{array}$ & $\begin{array}{l}-0.212^{*} \\
* *\end{array}$ & $0.479 * * *$ & 1 & 0.103 & 0.004 & $0.282^{* * *}$ \\
\hline RSR & -0.013 & 0.004 & 0.038 & 0.103 & 1 & $0.188^{* *}$ & -0.051 \\
\hline R\&D Ratio & -0.037 & -0.055 & 0.004 & 0.004 & $\begin{array}{l}0.188^{*} \\
* *\end{array}$ & 1 & 0.044 \\
\hline VC_Period & -0.097 & $\begin{array}{l}0.480^{* *} \\
*\end{array}$ & $-0.133^{* *}$ & $-0.282^{* * *}$ & -0.051 & 0.044 & 1 \\
\hline
\end{tabular}

Note: $* * *$ indicates significant at the 0.01 level (bilateral); $* *$ indicates significant at the 0.05 level (bilateral); * indicates a significant level at the 0.1 level (bilateral).

Multivariate Regression Test and Analysis. This part uses multiple regression model to test the effect of the interpreted variables of the samples on the performance of the listed companies' venture capital, and table 4 gives the results of the regression.

Table 4 Regression Results of Multivariate Linear Model

\begin{tabular}{|c|c|c|c|c|c|c|c|}
\hline & & \multicolumn{3}{|c|}{ BR(output level) } & \multicolumn{3}{|c|}{ IRR(benefit level) } \\
\hline & & $\begin{array}{l}\text { coefficie } \\
\text { nt }\end{array}$ & $\begin{array}{l}\text { The } \\
\text { value } \\
\text { of } T\end{array}$ & $\begin{array}{l}\text { The } \\
\text { value } \\
\text { of } F\end{array}$ & $\begin{array}{c}\text { coefficie } \\
\text { nt }\end{array}$ & $\begin{array}{l}\text { The } \\
\text { value of } \\
\mathrm{T}\end{array}$ & $\begin{array}{l}\text { The } \\
\text { value } \\
\text { of } F\end{array}$ \\
\hline \multirow[t]{2}{*}{ Model 1} & VC_Number & $\begin{array}{l}-0.338 * * \\
*\end{array}$ & -1.995 & 6.9 & $\begin{array}{l}1.62 \mathrm{E}-0 \\
5\end{array}$ & $\begin{array}{l}6.77 \mathrm{E}-0 \\
5\end{array}$ & 6.081 \\
\hline & VC_Relationship & $\begin{array}{l}-11.721^{*} \\
* *\end{array}$ & -3.983 & 8.59 & $\begin{array}{l}-0.004 * \\
* *\end{array}$ & -2.894 & 5.29 \\
\hline \multirow[t]{3}{*}{ Model 2} & RSR & -0.202 & -0.132 & 8.557 & $0.159 *$ & 1.726 & 11.854 \\
\hline & R\&D Ratio & -0.102 & -0.703 & 8.628 & $0.197 *$ & 1.952 & 11.701 \\
\hline & VC_Period & $\begin{array}{l}\text { 6.506** } \\
*\end{array}$ & 5.157 & 8.781 & $\begin{array}{l}-1.725 * \\
* *\end{array}$ & -10.423 & 34.144 \\
\hline \multirow[t]{3}{*}{ Model 3} & $\begin{array}{l}\text { VC_Relationship } \\
\times \text { RSR }\end{array}$ & $\begin{array}{l}-24.038 * \\
* *\end{array}$ & -2.747 & 7.32 & $\begin{array}{l}-0.157 * \\
* *\end{array}$ & -2.993 & 14.536 \\
\hline & $\begin{array}{l}\text { VC_Relationship } \\
\times \mathrm{R} \& \mathrm{D}\end{array}$ & $\begin{array}{l}-73.763 * \\
* *\end{array}$ & -2.695 & 7.396 & $\begin{array}{l}-0.258 * \\
* *\end{array}$ & -4.963 & 17.335 \\
\hline & Samples & 224 & 224 & 224 & 224 & 224 & 224 \\
\hline
\end{tabular}

Note: $* * *, * *, *$ are marked on the $0.01,0.05$, and 0.1 levels, respectively.

The regression results of model 1 can be seen from table 4 , in the BR index, the regression coefficients of VC_number is -0.338 , the regression coefficients of VC_relationship is -11.721 , both show a negative correlation at the significance level of 0.01 ; in the IRR index, no significant correlation between VC_number and IRR of listed companies; while VC_relationship has negative significant at the $1 \%$ level to IRR, the regression coefficient is -0.255 . The regression results are contrary to the assumption 1 . The reason lies in: (1) in the early development stage of enterprise, even if there has a large number of venture capital institutions, and the cooperation between them is 
closely related, the existing resources can not completely play and effectively applied to practical projects, which will not lead to the improving of investment performance;(2)venture investment institutions in the project selection and the process of investment can not accurately grasp the future development trend of the project, a good project in the early might not have the potential, so venture capital institutions may not look good for this project, even if the cooperation relation between them is quite deep, this will lead insufficient investment and can not produce the desired performance of investment;(3) due to the cluster effect or good reputation of venture capital institutions, both sides have a sense of trust in cooperation, it will gradually lose the binding force of mutual assistance and supervision, and can not get the expected return on investment performance in the follow-up cooperation process.

It can be seen from the regression results of industry characteristics of model two, the benefit level index of venture captal performance is better than the output level of performance, in the IRR index, R\&D ratio is positively correlated to IRR at significance of 0.1 level, and research staff ratio as well, the more research staff ratio and funding ratio, the more chances to improve the internal rate of return of venture capital. This shows that research staff ratio and $R \& D$ ratio have a certain influence in describing the characteristics of the industry enterprises, especially in the field of new and high technology, venture capital institutions study the index such as research staff ratio, R\&D ratio, core technology products ratio and other indicators in this field, in order to decide whether to invest the project to achieve high returns, while to have implementation of professional investment and management, feasibility of the project and innovation are project selection criteria of venture capital institutions, therefore, in the equilibrium state, investors will invest in the desired industry characteristics of the enterprise. To a certain extent, this support hypothesis 2.

VC-period has a positive significant to BR in the 0.01 level, the longer the holding time of venture investment project is, the higher the book return multiples, the reason is that VC-period represents a potential investment level, to a certain extent, it also shows the stage of entrepreneurs, investors appetite for investing mature enterprises, thus avoiding the cost loss caused by understanding of different enterprises frequently, investment projects and entrepreneurs, make the capital invest to more potential projects, thus improving the book return multiples. VC-period has a negative significant to IRR at 0.01 level, partly because the IRR is calculated by the formula (1+BR) $\wedge(1 / T)-1$, and when the holding time is longer, in addition to the increasing cost, due to the impact of the external environment of investment project, such as market risk, legal system and policy, long time to hold venture project will increase the uncertainty, which reduce the internal rate of return. Therefore, it can be concluded that the longer the holding time of the venture investment project is, the better the performance of the venture capital is at the output level.

From the regression results of model three, we can see that the assumption that the partners correlation and industry characteristics have a positive impact on the investment performance of listed companies, the result is not valid for hypthesis 4. Cross variables like partners correlation and research staff ratio, partner correlation and $R \& D$ funds are significantly enhanced the negative correlation on the performance of investment, namely in terms of output level index or the benefit level index, VC_relationship * research staff ratio and VC_relationship * R\&D ratio have negative correlation significantly to BR and IRR at 0.01 level. The reasons are: (1) in the case of partner correlation consistent, return on corporative investment is uncertainty, serious agency problems are exist, knowledge and technology are not mature, and uncertain factors have occurred in the early stage of venture enterprises, these caused a negative investment performance; (2) keep the field of business investment in certain circumstances, staff employment and R\&D funds in internal development of enterprises need to pay a certain cost, venture capital institutions saw investment losses is far greater than the benefits, therefore, they will gradually show the lack of sense of responsibility, exit investment projects early or have liquidation behavior, resulting in negative correlation of risk investment performance significantly.

Combine the hypothesis 2, in the high-tech fields with certain obvious industry characteristics, the employment of research staff and $R \& D$ expenditures of entrepreneurial firm unilaterally play a certain role in whether to invest a project or increase the investment performance, that is to say, 
increasing the research staff ratio or $\mathrm{R} \& \mathrm{D}$ ratio will help to improve the benefits level of investment performance. But in terms of the output performance BR, according to the theory and results of this study, the reasons why cross variables enhanced negative correlation significantly to output level of investment lie in: (1) when there is a certain number of venture capital institutions and they have closer relationship, the institutions will show low sense of responsibility and high probability of breach rate when the project of funded enterprises facing failed, caused the failure of the project and enterprises facing the brink of bankruptcy; (2)venture capital institutions have limited time and energy, under the condition of greater numbers and closer relationship, there are more coordination costs when members participate in the process of post investment management, which leads to social degradation and degressive efforts accordingly; (3)venture capital institutions take the staged investment strategy cautiously to realize their own interests, finding any negative information about future returns, they will be terminated following financing, this way restrains input in project development phase and acquisition of tangible assets in production stage in a certain extent in the venture investment, indirectly affect the performance of investment returns. Therefore, the joint selection of partners' association and industry characteristics will have a significantly negative correlation with the investment performance of venture capital. But in the high and new technology field with obvious industry characteristics, the choice of industry characteristics has an obvious positive impact on the investment performance of the venture capital efficiency level.

\section{Conclusion}

This paper from the perspective of enterprise partners and industry characteristics studies its impact on the performance of listed companies' venture capital. Based on the 224 listed companies with venture capital background of Shenzhen stock exchange in Wind database from 2009 to 2017, this study shows that: In the economic background of listed companies, venture capital partners effect showed negative influence; Associate degree of partners and the characteristics of the industry will have a significant negative correlation on venture capital investment performance, but in the field of new and high technology industry, the selection of certain characteristics of the industry positively have active influence on the benefit level performance of venture capital investment; The holding time of venture capital project has a significantly positive effects on the output level of venture capital investment performance.

The innovation of this paper is embodied in the perspective of studying enterprise partners and industry characteristics, and discusses the relationship between them and venture capital performance of listed companies. This study is a tentative and pioneering discussion in improving venture capital performance of listed companies. Following research can be studied in the same direction.

\section{Reference}

[1] Xueyong Zhang and Liao Li: Venture capital background and company IPO: market performance and internal mechanism]. Economic Research, (2011) No.6, pp.119-132.

[2] Yongping $\mathrm{Li}$ and Chengou Juan: The effect of venture capital on the performance of listed companies after IPO -- Based on empirical evidence of the gem. Accounting Friends, (2017) No.5, pp.73-77.

[3] Bottazzi L, Rin M. D and Hellmann T: Who are the active investors? evidence from venture capital. Journal of Financial Economics, Vol.89 (2008) No.3, pp.488 -512.

[4] Baum J. A. C and Silverman. B. S: "Picking winners or building them? Alliance, intellectual, and human capital as selection criteria in venture financing and performance of biotechnology startups". Journal of Business Venturing, Vol.19(2004) No.3, pp.411-436.

[5] Zhirong $\mathrm{Mu}$, Yinglu $\mathrm{Li}$ : Is the value-added activities of venture capital really useful? Empirical Evidence from the small and medium listed companies in Shenzhen. Investment Research, (2012) No.2, pp.67-77.

[6] Mingshan Zhou, Chunwei Wang and Shihai Huang: The influence of transfer of control rights 
on investment performance of state-owned holding companies -- Based on the perspective of investment and stock returns. International Financial Research, (2013) No.10, pp.74-85.

[7] Shijun Zhang: Overseas market orientation, entry mode selection and investment performance -- Based on the microdata of Shanghai and Shenzhen listed companies.Accounting Monthly, (2017) No.15, pp.46-50.

[8] Chao Deng and Yihan Liu. Influence of professional investment intensity on enterprise innovation ability in venture capital industry. Technology Progress and Countermeasures, (2017) No.5, pp. 80-85.

[9] Yan Li, Guofeng Luo, Xintian Zhuang and Shimei Ma. Risk investment strategy and investment performance -- An Empirical Study Based on Chinese risk investment institutions. Investment Research, (2012) No.11, pp.88-100.

[10] Chuancai Ye and Lianxiang pan: Research on Association of risk investment performance and risk investment fund investment behavior. Enterprise Economy, (2012) No.2, pp.159-161.

[11] Gupta. A and Sapienza. H: "Determinants of venture capital firms'preferences regarding the industry diversity and geographic scope of their investments".Journal of Business Venturing, Vol.7 (1992) No.5, pp.347-362.

[12] Dimov. D and De Clercq. D: Venture capital investment strategy and portfolio failure rate: A longitudinal study. Entrepreneurship Theory and Practice, Vol.30 0(2006) No.2, pp.207-223.

[13] Kaplana and Stromberg: Financial Contraeting Theory Meets the Real World.Review of Economic Studies,(2003) No.70, pp.281-315.

[14] Chengming Xu, Rui Xia, Wei Deng. An Empirical Study on venture capital investment [J]. Economic Dynamics, (2009) No.10, pp.112-116.

[15] Gompers Lerner. Venture Capital Distributions. Journal of Finance,(1998)No.6,pp.2161-2183.

[16]Lerner J:The syndication of venture capital investments. Financial management, (1994), pp.16-27.

[17] Du. Q:Birds of a feather or celebrating differences? The formation and impact of venture capital syndication. Unpublished Working Paper, (University of British Columbia, 2009).

[18]Bing Feng, Minli Yang and Feng Wang: The impact of stage investment on investment performance of venture capital institutions: the regulatory role of the investment region. Scientific Research Management, (2016) No.2, pp.124-131.

[19]Liufen $\mathrm{Hu}$ and Weitao Shen: The impact of joint investment strategy on venture capital performance research. Securities Market Guide, (2014) No.11, pp.8-20.

[20] Yan Li, Xintian Zhuang, Guofeng Luo and Ma Shimei: Risk investment institutions of human capital and investment performance: mediating and moderating effect of investment strategy. Journal of Northeastern University (NATURAL SCIENCE EDITION), (2012) No.11,pp.1660-1668.

[21]Longbing Xu and Dafang Zhang: "Smart investors" in China's stock market "behavioral research. Financial Research, (2017) No.4, pp.96-108.

[22] Weitao Shen and Liu Fen Hu. The influence and mechanism of professional investment strategy on venture capital performance. Journal of Shanxi University of Finance and Economics, (2014) No.5, pp.42-53.

[23] Humphery-Jenner. M: Diversification in Private Equity Funds:On knowledge sharing, risk aversion and limited attention. Journal of Financial and Quantitative Analysis, (2013) Forthcoming.

[24] Dimov. D, Shepherd. D. A and Sutcliffe. K. M: Requisite expertise, firm reputation, and status in venture capital investment allocation decisions.Journal of Business Venturing, Vol.22 (2007) No.4, pp.481-502.

[25] Das. S. R, Jo. H and Kim. Y: Polishing diamonds in the rough: The sources of syndicated venture performance. Journal of Financial Intermediation, Vol.20 (2011) No.2, pp.199-230.

[26] Argote. L: “Organizational learning curves: persistence, transfer and turnover"International. Journal of Technology Management, Vol.11 (1996) No.7-8, pp.759-769.

[27]Fried. V. H, Bruton. G. D and Hrisrich. R. D: "Strategy and the Board of Directors in Venture 
Captial-backed Firms”. Journal of Business Vrntureing, Vol.13 (1998) No.6, pp.493-503.

[28] Gompers. P. A: Optimal investment ,monitoring, and the staging of venture capital. The Journal of Finance, Vol.50 (1995) No. 5, pp.1461-1489.

[29]Faria. A. P and Barbosa. N: Does venture capital really foster innovation. Economics Letters, Vol.122 (2014) No. 2, pp.129-131. 